\title{
Impact of Molybdenum on Heat-Treatment and Microstructure of ADI
} \\ ${ }^{1}$ Clausthal University of Technology - Institute of Metallurgy, \\ Robert-Koch-Str. 42,38678 Clausthal-Zellerfeld, Germany \\ a Julius.Alexander.Gogolin@tu-clausthal.de, \\ bBabette.Tonn@tu-clausthal.de \\ ${ }^{*}$ corresponding author
}

Keywords: ADI, molybdenum, dilatometer, heat-treatment, ausferrite, carbides

\begin{abstract}
Austempered Ductile Iron (ADI) is characterized by high tensile strength with acceptable ductility. Steel, as a large competitor to ADI, also meets the tensile and yield strength. Nevertheless, the main advantages of ADI compared to steel are the lower density $\left(7.2 \mathrm{~g} / \mathrm{cm}^{3}\right.$ to $\left.7.85-7.87 \mathrm{~g} / \mathrm{cm}^{3}\right)$ for weight reduction and lower manufacturing costs because of less energy consumption during the production.
\end{abstract}

One of the main problems of producing ADI is the quenching process during heat treatment of thick-walled castings. The inner part of a massive casting - in contrast to the outer part - cools down more slowly, resulting in a heterogeneous microstructure with parts of pearlite and ferrite embedded in austenite before reaching the isothermal transformation temperature.

Molybdenum is, besides nickel, copper and manganese, one of the possible alloying elements that postpone the transition point of ferrite and/or pearlite.

To investigate the influence of molybdenum in thick-walled castings experiments with different molybdenum contents were performed. In dependence on the molybdenum content, different austenisation and ausferritisation temperatures and times are examined in order to investigate the transformation points, fraction and morphology of different phases.

The mechanism of molybdenum in ADI has been investigated by means of dilatometer tests, microstructure analysis and mechanical tests.

\section{Introduction}

Austempered malleable iron is known since the 1960s. In the early to mid-1970s, Austempered Ductile Iron (ADI) got useable for the industry. Initially, ADI was used for small parts without security relevance [1]. After a few decades of development, ADI is only partially successfully established in the European foundry industry. It is at present not useable for thick walled castings due to the need of heat treatment. However, nowadays, lightweight construction is becoming more and more important and ADI can be used for lightweight castings, despite the heavy weight image of ductile iron. The tensile strength of ADI can be compared to steel, as the specific density of ADI with $\rho_{\mathrm{ADI}}=7.2 \mathrm{~g} / \mathrm{cm}^{3}$ is lower than that of steel $\rho_{\text {steel }}=7.85-7.87 \mathrm{~g} / \mathrm{cm}^{3}$ [2]. This is a difference of about $10 \%$ due to the graphite nodules in ADI. Compared to aluminium, the tensile strength of ADI is three times as high, but the mass is only 2.6 times higher [2]. Due to the nature of the ADI structure, it has a very good wear resistance compared to conventional steels since the residual austenite is hardened under mechanical stress by cold forming or even transformed into stressinduced martensite [2]. Also the ratio production costs to strength for ADI is superior to steel or aluminium [2]. It should also be mentioned, that ADI is a good conductor for heat and a better damper for vibration than steel [3,4]. According to [2], nearly $80 \%$ of all casted and forged steel parts can be replaced by parts consisting of ADI. With these advantages ADI becomes a good alternative to other materials.

However, castings with great wall thicknesses are not able to be heat treated in the way, as it is necessary to the production of ADI. The heat treatment consists of four steps. The first step is heating and austenitisation at temperatures between $840{ }^{\circ} \mathrm{C}$ and $950{ }^{\circ} \mathrm{C}$. The dwell depends on the 
nodule count, the chemical composition and the sample geometry [2] and must be long enough to saturate the austenite with carbon. At the second step, after reaching the end of austenitisation, the casting is transferred rapidly to a salt bath furnace with an austempering temperature between $280^{\circ} \mathrm{C}$ and $390^{\circ} \mathrm{C}$ [5]. It must be quenched very fast to keep the austenite phase [6]. At step three, while holding the ausferritisation temperature, ferrite precipitates from the austenite. Thus, austenite will be enriched by carbon and stabilised. With decreasing ausferritisation temperature the microstructure will get finer and the strength increases. Step four is the end of the heat treatment. Just before reaching the bainite area, the casting is cooled down on air to keep the ausferritic microstructure and to avoid residual stress.

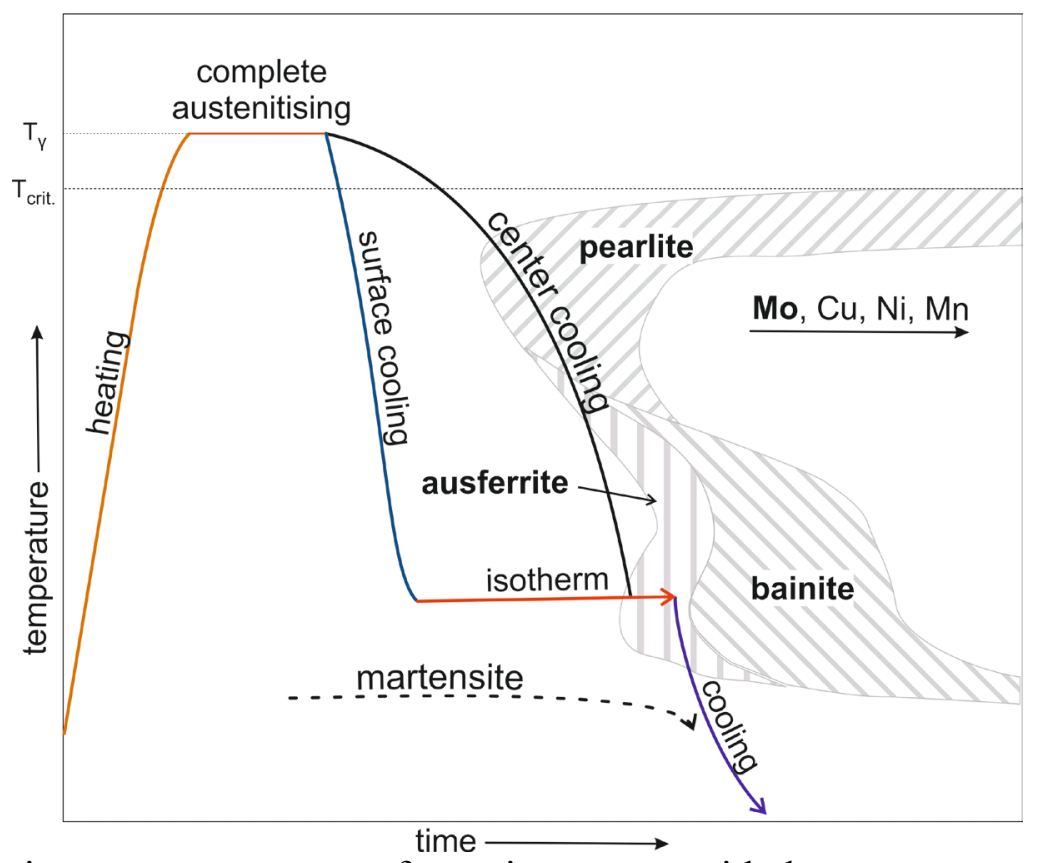

Fig. 1. Schematic time-temperature-transformation curve with heat treatment of a thick-walled casting (according to [7]).

Thick walls in a casting are not able to be cooled down fast enough in each area for a good result in mechanical properties. Fig. 1 schematically shows the difference between surface and centre cooling. While the near-surface areas cool down fast enough to reach the isothermal transformation temperature with austenite structure the center area loses its temperature much more slowly. That leads to a pearlitic microstructure which is undesired and results into poor mechanical values.

\section{Theory}

Alloying elements like copper, nickel, manganese and molybdenum postpone the transition time of ferrite and perlite $[2,8]$, so there is more time for the central areas to cool down to austempering temperature without eutectoid transformation.

In [7] the effect of nickel is investigated in detail. Nickel also has a good effect on the pearlite nose movement to later pearlite transformation times. However, nickel restricts the solubility of carbon, so the mechanical properties are reduced [7].

Molybdenum on the other hand does not reduce the carbon solubility in austenite, so higher mechanical properties are expected.

In this paper, the effect of molybdenum in ductile cast iron for the production of ADI is investigated.

\section{Properties of Molybdenum}

Molybdenum as an alloying element in ferritic or pearlitic cast iron has some positive but also negative properties. According to [9] molybdenum restricts the austenite area and slows down the 
transformation start to pearlite by increasing the eutectoid temperature. In [10] is shown, that a cast iron with $3.62 \mathrm{wt} \% \mathrm{C}, 2.32 \mathrm{wt} \% \mathrm{Si}, 0.30 \mathrm{wt} \% \mathrm{Mn}, 0.1 \mathrm{wt} \% \mathrm{Ni}$ and $0.5 \mathrm{wt} \% \mathrm{Mo}$ has a "pearlite time" of nearly $100 \mathrm{~s}$.

An addition between 0.1 and $0.3 \mathrm{wt} \%$ of molybdenum acts ferrite stabilising [9]. Molybdenum is responsible for a higher tensile strength [11] but in combination with nickel or copper the strength gain would be more effective [9].

Molybdenum has the biggest influence on hardenability $[12,13]$ combined with the advantage of smallest influence on elongation [13]. The addition of up to $2.0 \mathrm{wt} \%$ of molybdenum raises bending cycle, creep resistance and hot fatigue strength as well as the dimension accuracy at elevated temperatures [12]. The report [14] shows, that a rising molybdenum content has a small influence on the nodularity.

In accordance with [9] the addition of at least $1.0 \mathrm{wt} \%$ of molybdenum has a slight carbide stabilizing effect. Oppositional [12] shows, with an addition of $0.3 \mathrm{wt} \%$ molybdenum carbides start to grow at the grain boundaries. The addition of $0.33 \mathrm{wt} \%$ and $0.74 \mathrm{wt} \%$ molybdenum, respectively, results in a diminishment of the tensile and yield strength due to embrittlement evoked by the carbides [14]. Especially for ausferritic microstructure, a higher molybdenum content leads to decreasing elongation [14] when ausferritised at temperatures above $300{ }^{\circ} \mathrm{C}$ because of the carbides [6]. In turn, [15] shows, that the brittle segregation zone in the grain boundary areas, where you can find molybdenum, are predestined for early cracks. In [16] it is shown that, with rising molybdenum content the pearlite content also increases. Next to the molybdenum segregations [16] found pearlitic structure.

\section{Experimental Work}

\section{Casting}

For casting the samples, three Y4-moulds were build. The moulds consist of quartz sand with furan resin and acidic hardener. The melt has been prepared based on $70 \%$ pig iron and $30 \%$ steel scrap. The materials were melt in an inductive ladle furnace. The melt composition was adjusted at $1400{ }^{\circ} \mathrm{C}$ subsequently heated to $1500{ }^{\circ} \mathrm{C}$. The magnesium treatment has been done at a temperature of $1450{ }^{\circ} \mathrm{C}$, followed by the inoculation and pouring at $1360{ }^{\circ} \mathrm{C}$. The actual values of the composition of the ductile iron (DI) used in this study are shown in Table 1.

Table 1. Actual values of examined DI specimens.

\begin{tabular}{l|cccccccc}
\hline & $\mathrm{C}$ & $\mathrm{Si}$ & $\mathrm{Mo}$ & $\begin{array}{c}\mathrm{Mn} \\
{[\mathrm{wt} \%]}\end{array}$ & $\mathrm{Ni}$ & $\mathrm{Cu}$ & $\mathrm{Mg}$ & $\mathrm{S}_{\mathrm{C}}$ \\
\hline $\mathrm{V} 1-0.0 \mathrm{wt} \% \mathrm{Mo}$ & 3.59 & 2.44 & 0.00 & 0.056 & 0.004 & 0.012 & 0.033 & 1.04 \\
$\mathrm{~V} 2-0.3 \mathrm{wt} \% \mathrm{Mo}$ & 3.72 & 2.49 & 0.29 & 0.048 & 0.004 & 0.014 & 0.038 & 1.07 \\
$\mathrm{~V} 3-0.6 \mathrm{wt} \% \mathrm{Mo}$ & 3.67 & 2.52 & 0.61 & 0.052 & 0.003 & 0.016 & 0.043 & 1.07 \\
\hline
\end{tabular}

\section{Sample Preparation}

For further investigations, hardness, microstructure and dilatometer samples and tensile test billets (for machining after heat treatment) were produced.

For the dilatometer testing, samples of $10 \mathrm{~mm}$ length by $5 \mathrm{~mm}$ diameter were turned. The samples were equipped with thermocouples for temperature measurement.

\section{Dilatation}

To identify the different transformation times of austenite to ferrite/pearlite or to ausferrite/bainite, eight dissimilar temperature curves, see Table 2 and Fig. 2, were performed. 
Table 2. Specifications for heat treatment.

\begin{tabular}{l|ccccc}
\hline & 1 & 2 & 3 & 4 & 5 \\
\hline temperature & RT to 920 & 920 & 920 to $750 / 700 / 650 / 600$ & $\begin{array}{c}\text { equivalent } \\
\text { temperature }\end{array}$ & to RT \\
{$\left[{ }^{\circ} \mathrm{C}\right]$} & & & 920 to 350 & 0 & -10 \\
heating rate & 1 & 0 & -100 & 7200 & $20-23$ \\
$\begin{array}{l}{[\mathrm{K} / \mathrm{s}]} \\
\text { time }[\mathrm{s}]\end{array}$ & 900 & 5400 & $2-6$ & & \\
\hline
\end{tabular}

The temperature regimes from $750{ }^{\circ} \mathrm{C}$ to $600{ }^{\circ} \mathrm{C}$ were chosen for identifying the ferrite/pearlite nose. The temperature of $350{ }^{\circ} \mathrm{C}$ was selected for the phase transformation from austenite to ausferrite and ausferrite to bainite, respectively. A EN-GJS-1050-6 is expected. The samples where heated, austenitised and ausferritised under vacuum to prevent oxidation.

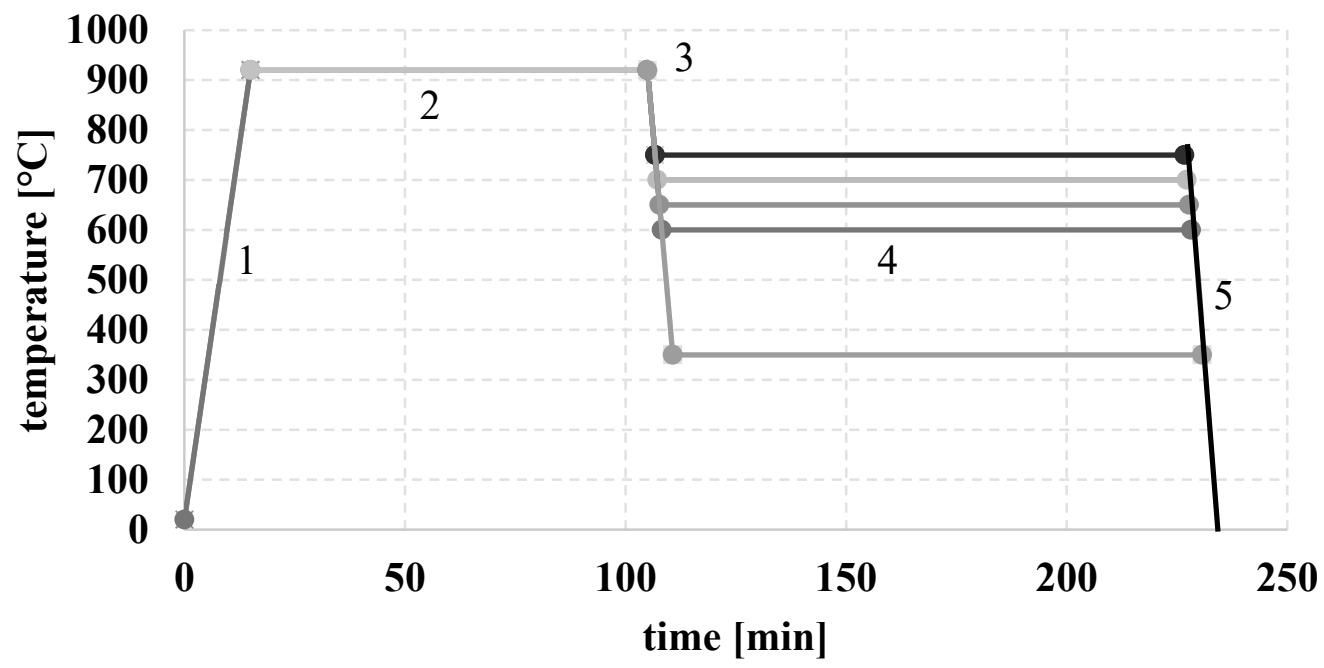

Fig. 2. Different heat treatment curves driven with the dilatometer.

With the chosen transformation time, derived from the dilatation curve at $350{ }^{\circ} \mathrm{C}$, the tensile test billets where first heated and austenised in a muffle oven and then quenched and ausferritised in a salt bath furnace. Afterwards tensile test specimens (DIN EN ISO 6892-1 type B) were turned and investigated and the hardness (DIN EN ISO 6506-1) was measured.

\section{Results and Discussion}

\section{Microstructure in as cast state}

Table 3 shows the nodularity, the fraction of pearlite and ferrite and the intercellular MoCarbides (Fig. 3, left). With the addition of molybdenum the nodularity is improved moderately. With higher molybdenum content, the pearlite fraction and the intercellular carbides increase.

Table 3. Influence of Mo on nodularity, the pearlite and ferrite ratio and intercellular Mo-Carbides.

\begin{tabular}{l|cccc}
\hline & nodularity & ferrite & pearlite & $\begin{array}{c}\text { intercellular } \\
\text { Mo-Carbides }\end{array}$ \\
& & & {$[\%]$} & \\
\hline V1 - 0.0 wt\% Mo & 76.3 & 85.8 & 3.2 & 0 \\
V2 - 0.3 wt\% Mo & 82.9 & 82.6 & 5.8 & 0.07 \\
V3 - 0.6 wt\% Mo & 81.7 & 78.8 & 9.6 & 0.27 \\
\hline
\end{tabular}

In Fig. 3 on the left, there is a detail of the microstructure of V3 in as cast state. It is etched with nital [17]. A fishbone pattern Mo-Carbide is visible. It is surrounded by pearlitic structure. The right picture, also V3 but already heat treated and color etched with LePera [17], shows some bright 
carbide belts, not only Mo-Carbides. The microhardness at the bright carbide belts was measured with about $770 \mathrm{HV} 0.025$ for the carbides and $463 \mathrm{HV} 0.025$ for the ferrite areas.
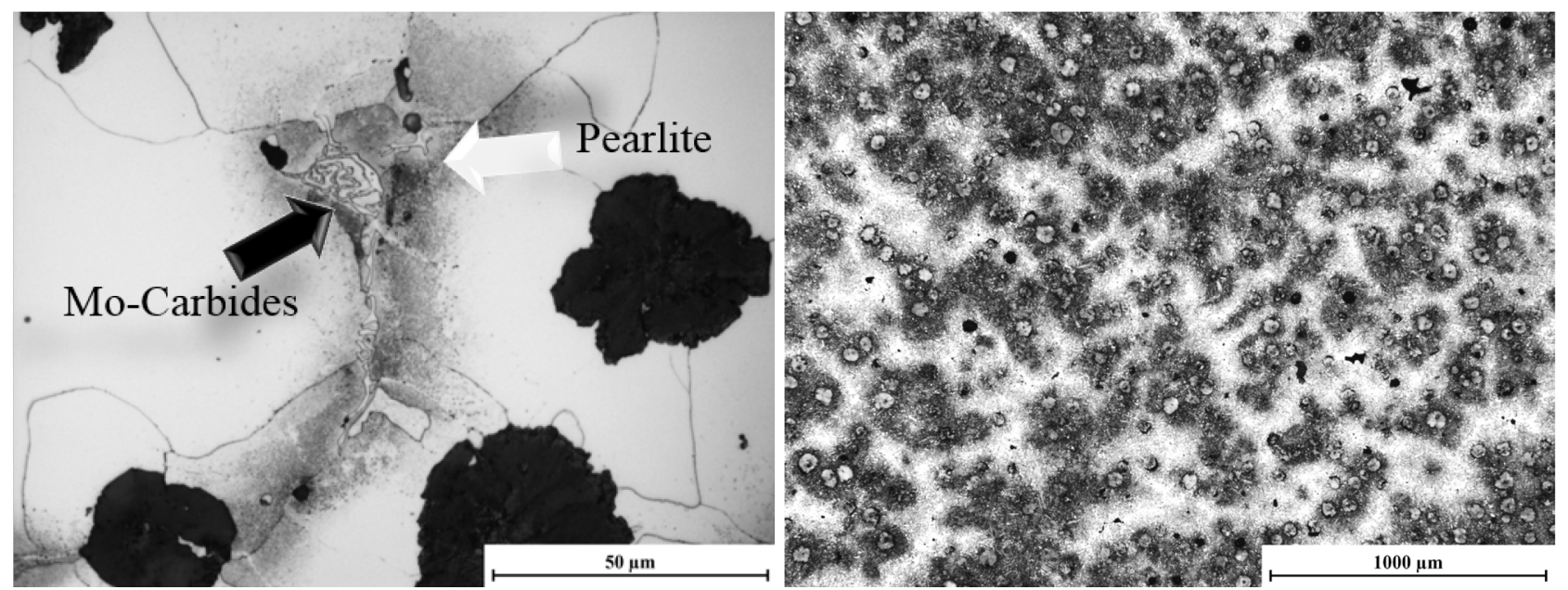

Fig. 3. Left: Light microscope, V3 $0.6 \mathrm{wt} \% \mathrm{Mo}$, as cast, 1000x, etched with nital, pearlitic structure surrounds molybdenum carbides (fishbone pattern) - Right: Light microscope, V3 $0.6 \mathrm{wt} \% \mathrm{Mo}$, heat treated, 50x, etched with Le Pera, bright carbide belts.

The microstructure in the as cast state (Table 3) shows the statement of [16]; with a higher amount of molybdenum, more pearlite is built in direct surroundings of the molybdenum carbides at the grain boundaries. In [18] it is also shown, that with rising molybdenum content the intercellular carbides ascend.

\section{Mechanical Properties}

In as cast state (Fig. 4), molybdenum enhances the tensile strength from $397 \mathrm{MPa}$ to $441 \mathrm{MPa}$. The elongation also increases with a higher amount of molybdenum from $18.3 \%$ to $20.7 \%$, but at $0.6 \mathrm{wt} \%$ it drops down to $13.5 \%$.

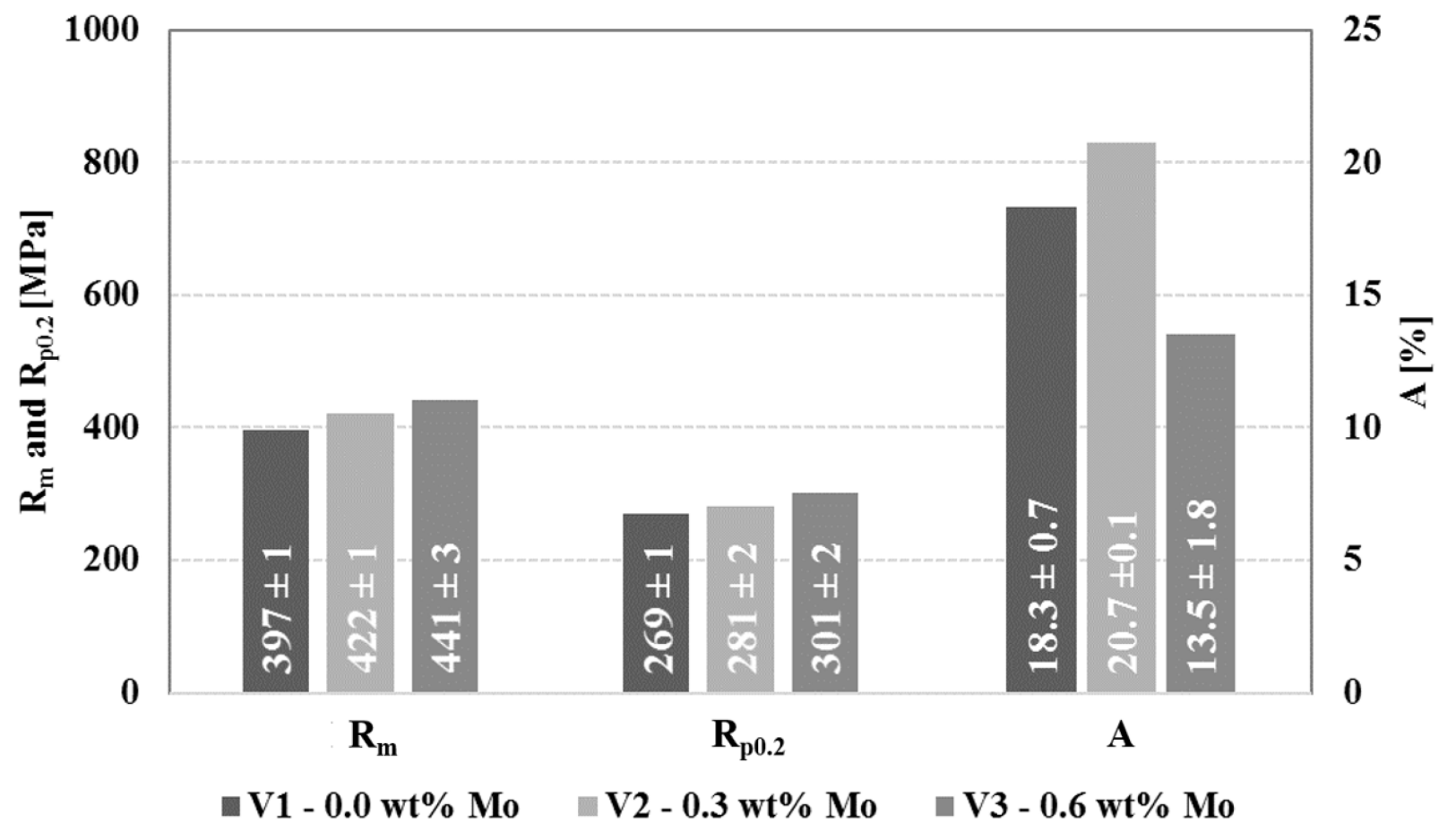

Fig. 4. Mechanical properties of the as cast material.

After heat treatment (Fig. 5) in a salt bath furnace the tensile and yield strengh are increased as expected. The elongation decreases to $1 \%$. The temperature of the salt bath settled between $350{ }^{\circ} \mathrm{C}$ 
and $360{ }^{\circ} \mathrm{C}$. The specimens where heat-treated for 55 minutes. Fig. 6 shows the hardness of the as cast material (V1 - V3) and the heat treated ADI (V1_HT - V3_HT). V1, without molybdenum, exhibits the lowest hardness with $140 \mathrm{HBW}$. With rising molybdenum content, the hardness also increases up to $150 \mathrm{HBW}$ in as cast state. The hardness of the heat treated ADI is more than twice as high. Highest hardness (367 HBW) can be found at V2_HT with $0.3 \mathrm{wt} \%$ molybdenum. Combining $0.6 \mathrm{wt} \%$ molybdenum and heat treatment lowers the hardness down to $334 \mathrm{HBW}$.

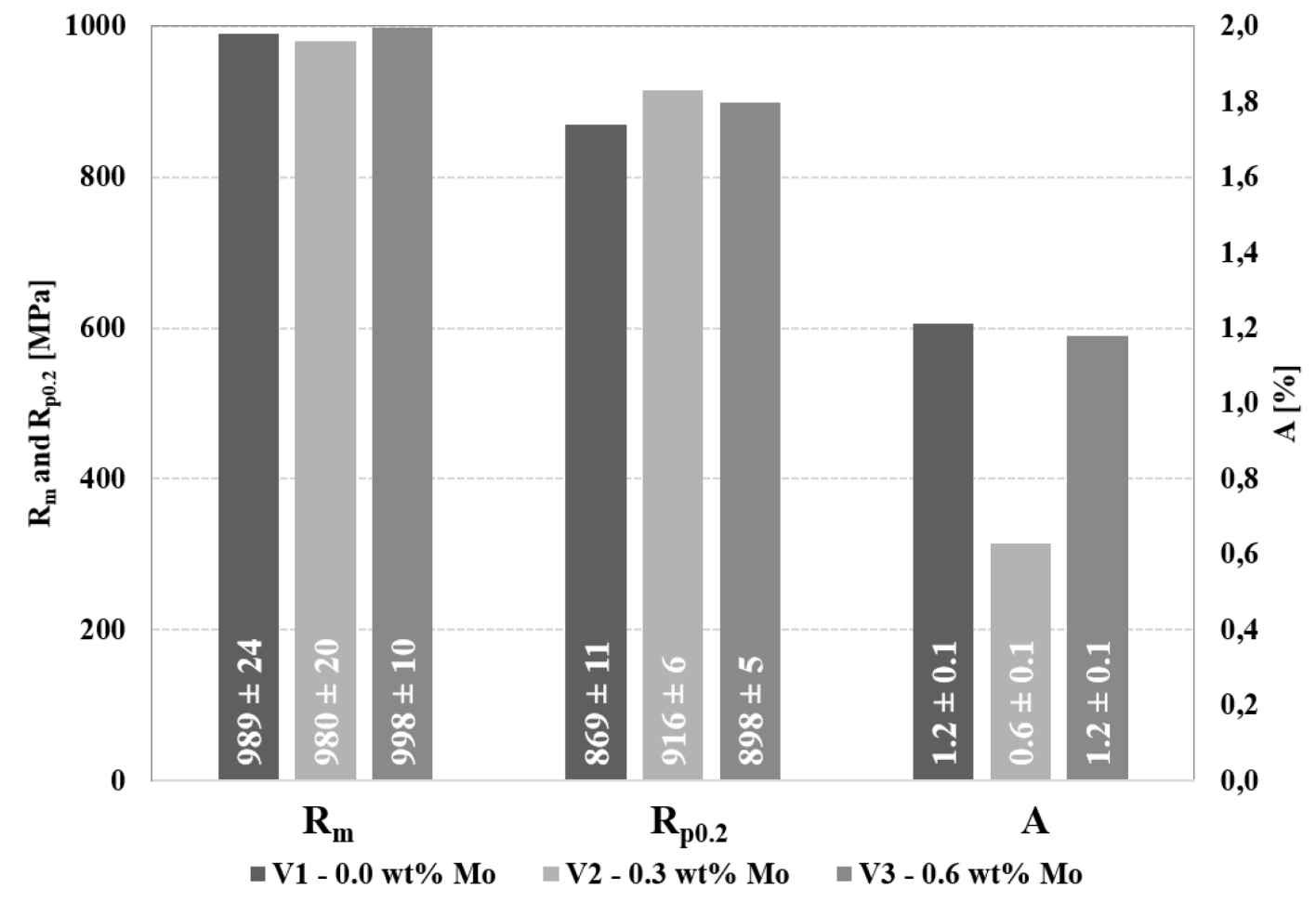

Fig. 5. Mechanical properties of the heat treated material.

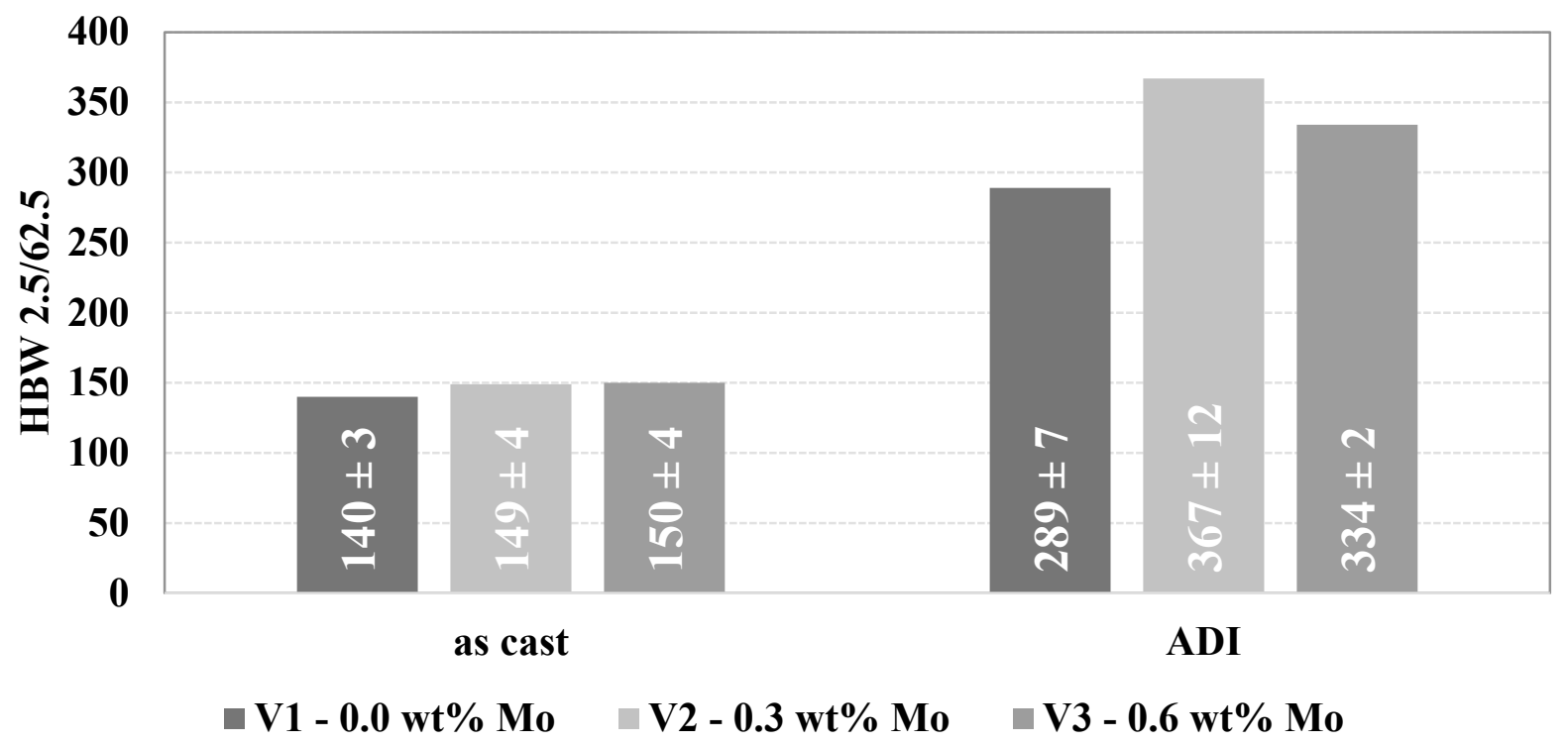

Fig. 6. Brinell hardness of as cast and heat treated specimens.

The as cast state also shows, that molybdenum rises the tensile and yield strength (Fig. 4) because of a larger amount of pearlitic structure. In accordance to [11], a nearly full ferritic structure has strength values of $400 \mathrm{MPa}$ and tensile values of $15 \%$. The achieved tensile and elongation values in the as cast state are between 400 and $440 \mathrm{MPa}$ and 13 to $20 \%$. Heat treatment was done in a salt bath furnace at $355^{\circ} \mathrm{C}$ until $360{ }^{\circ} \mathrm{C}$ for 55 minutes. The expected tensile strength and elongation at this ausferritising temperature were at $1050 \mathrm{MPa}$ and $6 \%$ according to DIN EN 
1564 [19]. The required tensile strength properties were nearly achieved, they are close to $1050 \mathrm{MPa}$ (Fig. 4). On the contrary, the elongation properties did not get the expected $6 \%$. The elongation values were at just $1 \%$. The elongation decrease could be associated with the molybdenum carbides, like $[6,14]$ show. In V2 and V3 a lot of carbides, molybdenum and others, were found (Fig. 3). The microhardness of the carbide belts were measured with $770 \mathrm{HV}$ 0.025 while the ferritic areas were measured with $463 \mathrm{HV} 0.025$. As well, the high yield strengths, in V2 and V3, give an indication of a strong matrix with a brittle failure. Also the experiment with $0.0 \mathrm{wt} \%$ molybdenum had very low elongation. The heat treatment at V1 did not work well, because the shifting time between austenitisation and austempering was too high and a big part of the microstructure changed to pearlite. Also without molybdenum, the time, when austenite changes to pearlite, is really short.

Molybdenum addition shows an effect at hardness (Fig. 6). With rising molybdenum content, the hardness rises from $140 \mathrm{HBW}(0.0 \mathrm{wt} \% \mathrm{Mo})$ up to $150 \mathrm{HBW}(0.6 \mathrm{wt} \% \mathrm{Mo})$, like shown in $[12,13]$. The ADI heat treatment increases the hardness more than double up to $367 \mathrm{HBW}$ at $0.3 \mathrm{wt} \%$ Mo. The expected hardness values for ADI are between 320 and $380 \mathrm{HBW}$ [19].

\section{Dilatation Curves}

Fig. 7 shows the influence of molybdenum on the postponement of the time critical earliest transformation from austenite to ferrite/pearlite. Molybdenum indicates an effect on the postponement. With $0.0 \mathrm{wt} \%$ molybdenum (V1) the earliest transformation time was $31 \mathrm{~s}$ after quenching at $650{ }^{\circ} \mathrm{C}$. The addition of $0.3 \mathrm{wt} \%$ molybdenum (V2) moves the critical time to $49 \mathrm{~s}$ at $650{ }^{\circ} \mathrm{C}$ and in $\mathrm{V} 3$ with $0.6 \mathrm{wt} \%$ the earliest transformation time after quenching was at $89 \mathrm{~s}$ at a temperature of $650{ }^{\circ} \mathrm{C}$.

Fig. 7 confirms the declaration of [9], where was stated that the addition of molybdenum slows down the transformation to pearlite [20].

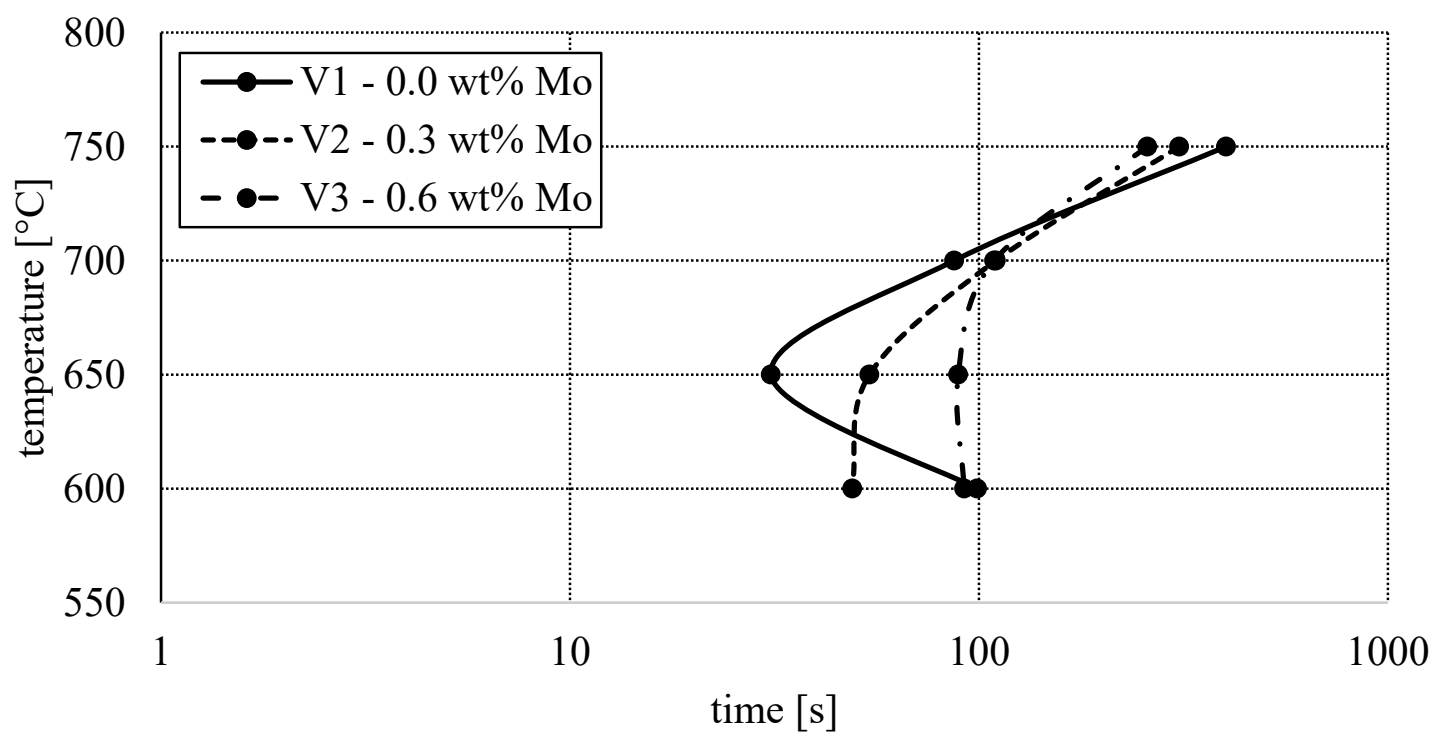

Fig. 7. Earliest time critical transformation times of austenite to ferrite/pearlite.

\section{Conclusion}

In this paper a standard DI with three different molybdenum contents is investigated concerning to the influence for thick walled ADI castings. The addition of $0.3 \mathrm{wt} \%$ and $0.6 \mathrm{wt} \%$ molybdenum as a singled alloying element shows an effect on the postponement of the ferrite/pearlite transformation. Combinations with additional elements like nickel and copper, showed by several other researchers, possess a better postponement of the first transformation to ferrite/pearlite. Molybdenum has an increasing effect on the tensile strength in the as cast state. The elongation in the heat treated ADI specimens was very low, because of carbides (molybdenum and others). 


\section{References}

[1] J.R. Keough, V.M. Popovski, Large Austempered Parts - Monster Opportunities, 2012.

[2] U. Wittwer, A. Rechsteiner, ADI - ein moderner Werkstoff mit vielfältigem Potenzial, castingJournal Dezember (2005).

[3] B.V. Kovacs, Austempered Ductile Iron: Fact and Fiction, modern casting (1990) 38-41.

[4] J.R. Keough, K.L. Hayrynen, K. L., Designing with Austempered Ductile Iron (ADI), Schaumburg, IL USA, 2010.

[5] S. Hasse, Gefüge der Gusseisenlegierungen: Structure of cast iron alloys, Schiele \& Schön, Berlin, 2008.

[6] S. Hasse, Duktiles Gußeisen: Handbuch für Gußerzeuger und Gußverwender, Schiele \& Schön, Berlin, 1996.

[7] P.G. Saal, Quantitative Phasenanalyse von ausferritischem Gusseisen mithilfe der Neutronendiffraktometrie. Dissertation, München, 2016.

[8] R. Deike, Einfluß von Spurenelementen auf die eutektische Erstarrung und die eutektoide Umwandlung von Gußeisen, GIESSEREI 86 (1999) 175-182.

[9] K. Röhrig, H.-G. Gerlach, O. Nickel, Legiertes Gusseisen - Gußeisen mit Kugelgraphit. Band 2, Giesserei-Verlag, Düsseldorf, 1974.

[10] K. Röhrig, Giesserei Kalender 1986: Taschenbuch der Giesserei-Industrie, Giesserei-Verlag GmbH, Düsseldorf, 1986, pp. 92-94.

[11] O. Liesenberg, D. Wittekopf (Eds.), Stahlguß- und Gußeisenlegierungen: Mit 56 Tabellen, first. Aufl., Dt. Verl. für Grundstoffindustrie, Leipzig, 1992.

[12] M. Gagné, Sorelmetal - Gusseisen mit Kugelgraphit, RIO TINTO IRON \& TITANIUM INC., Montreal (Quebec), Kanada, 2004.

[13] K. Röhrig, Niedriglegierte Gusseisenwerkstoffe, Gießerei-Praxis (1982) 1-12.

[14] A. Sobota, G. Wolf, W. Stets, A. Nissen, Einfluss von Gefügeabweichungen auf das Festigkeitsverhalten von ADI bei statischer, zyklischer und dynamischer Beanspruchung, GIESSEREI 99 (2012) 82-96.

[15] L.-Y. Fang, K.E. Metzloff, R.C. Voigt, C.R. Loper Jr., Der Elastizitätsmodul von graphitischem Gußeisen - Nachdruck des Vortrages Nr. TB-12 auf dem 61. GießereiWeltkongress 1995 in Beijing, 1995, Information on http://www.kug.bdguss.de/fileadmin/content/Publikationen-Normen-Richtlinien/buecher/EModul.pdf (accessed 25 August 2017).

[16] L. Dekker, Anwendung neuer Methoden in der Legierungsentwicklung am Beispiel eines warmfesten Gusseisens mit Kugelgraphit: Erkenntnisse zur Wirkung des Legierungselementes Molybdän. Dissertation, Clausthal-Zellerfeld, 2015.

[17] G. Petzow, Metallographisches, keramographisches, plastographisches Ätzen, seventh. leicht korrigierte Auflage, Gebrüder Borntraeger, Stuttgart, 2015.

[18] A.S. Benam, Effect of alloying elements on austempered ductile iron (ADI) properties and its process: Review, China Foundry (2015) 54-70.

[19] Normenausschuss Gießereiwesen (GINA) im DIN, Gießereiwesen - Ausferritisches Gusseisen mit Kugelgraphit; Deutsche Fassung EN 1564:2011 77.080.10, 1564, Beuthe Verlag GmbH, 2012 (Januar 2012) (accessed 5 August 2017).

[20] W. Schäfer, E. Hepp, J.C. Sturm, A. Heinrietz, W. Böhme, J. Heckman, U. Petzschmann, B. Pustal, H. Siebert, A. Stich, H. Müller, S. Schmidt, LEA - Leichtbau mit gegossenen ADI Bauteilen: Abschlussbericht, 2011 (30 June 2011), pp. 26-27 (accessed 15 August 2017). 